\title{
Curso Breve: "La tradición yámbica. Un acercamiento a la poesía yámbica de la Grecia arcaica y helenística" dictado por el Dr. Sebastián Carrizo
}

\author{
Facundo Oviedo \\ Centro de Estudios Helénicos- Instituto de Investigaciones en Humanidades y Ciencias Sociales- \\ Universidad Nacional de La Plata, Argentina \\ facundomartin@hotmail.com
}

Durante los días 3 y 5 de noviembre del 2020, el Centro de Estudios Helénicos del Instituto de Investigaciones y Ciencias Sociales de La Plata organizó de manera virtual —a través de la plataforma Zoom - el curso La tradición Yámbica. Un acercamiento a la poesía yámbica de la Grecia arcaica y helenistica. El mismo fue dictado por Sebastián Carrizo, profesor en Letras por la Universidad Nacional de Rosario y Doctor en Letras por la Universidad Nacional de La Plata, quien ha participado y participa de diversos proyectos de investigación sobre poesía griega arcaica y helenística.

El curso contó con la presencia de docentes, investigadores y alumnos de diferentes universidades nacionales, tales como la Universidad Nacional de Rosario, la Universidad Nacional del Litoral, la Universidad Nacional de San Juan, la Universidad del Nordeste, la Universidad Nacional de Buenos Aires y nuestra Universidad Nacional de La Plata pero también de universidades de distintos países de Latinoamérica como la Universidad de San Carlos de Guatemala, la Universidad Católica del Perú y la Universidade Federal do Rio Grande do Sul. Asimismo, tuvo representación el Colegio San Gregorio de Vicente López.

La actividad, que ambos días fue presentada por la Dra. Claudia Fernández, Directora del CEH, y coordinada por la Dra. María del Pilar Fernández Deagustini, se dividió en dos módulos de aproximadamente 90 minutos de duración: en el primero - de corte teórico- el Dr. Carrizo hizo una presentación introductoria pero detallada acerca de la tradición yámbica de la Grecia antigua, explicando los antecedentes y orígenes, sus características principales (formales, temáticas y performativas), cuáles fueron los autores más importantes, la función de la yámbica invectiva y la sátira personal y, finalmente, el trasfondo mítico y religioso que vincula la poesía yámbica con festividades y rituales pertenecientes a los cultos de Deméter y de Dioniso, haciendo hincapié en el uso tanto religioso como literario de las invectivas, las bromas obscenas, los disfraces y las máscaras; durante el segundo - que tuvo la modalidad de taller-, partiendo de ciertas nociones que Aristóteles postuló en Poética, se examinó una importante selección de textos poéticos de los principales autores yámbicos del período arcaico (Arquíloco de Paros e Hiponacte de Éfeso) y del período helenístico (Calímaco de Cirene) que sirvió para ejemplificar y reforzar los diversos elementos teóricos presentados en el módulo anterior.

Al final de cada uno de los encuentros, las coordinadoras dieron espacio para que los asistentes formularan preguntas al Dr. Carrizo o aportaran sus comentarios, enriqueciendo el intercambio académico y el espíritu de camaradería universitario.

Cita sugerida: Oviedo, F. (2020). Curso Breve: “La tradición yámbica. Un acercamiento a la poesía yámbica de la Grecia arcaica y helenística” dictado por el Dr. Sebastián Carrizo. Synthesis, 27(2), e093. https://doi.org/10.24215/1851779Xe093 